\title{
RESPON PERTUMBUHAN TANAMAN JATI PLUS PERHUTANI UMUR 11 TAHUN TERHADAP INTENSITAS PENJARANGAN DAN TUMPANG SARI (STUDI KASUS DI BKPH BEGAL KPH NGAWI, PERHUTANI JAWA TIMUR)
}

Growth response of selected teak clone aged 11 years to thinning intensity and intercropping (case study in Begal, Ngawi, East Java)

\author{
Muhammad Fadhil Amiruddin Sudomo ${ }^{1,2}$, Suryo Hardiwinoto ${ }^{1,3}$, Sapto Indrioko $^{1,3}$, Budiadi ${ }^{1,3}$, \\ Daryono Prehaten ${ }^{1,3}$, Aris Wibowo ${ }^{1,4}$ \\ ${ }^{1}$ Kontributor Utama, ${ }^{2}$ Universitas Palangka Raya, \\ Jl. H. Timang Kampus Universitas Palangka Raya, Kalimantan Tengah, Indonesia \\ ${ }^{3}$ Universitas Gadjah Mada, \\ Jl. Agro No. 1 Bulaksumur, Sleman, Daerah Istimewa Yogyakarta, Indonesia \\ email penulis korespondensi: suryohw@ugm.ac.id \\ ${ }^{4}$ Pusat Penelitian dan Pengembangan Perum Perhutani, \\ J1. Wonosari Tromol Pos 6 No 6, Brangkal, Batokan, Cepu, Jawa Tengah, Indonesia
}

Tanggal diterima: 19 Maret 2021, Tanggal direvisi: 07 Juni 2021, Disetujui terbit: 16 Juni 2021

\begin{abstract}
Thinning is one of silvicultural treatmens in maintaining and increasing growth and quality of standing stands. This study aims to determine growth response of selected teak clone to several intensities of thinning and intercropping. The method was a factorial completely randomized block design (RCBD) with thinning intensity (4 levels): $0 \%$ (control = A1), 25\% (A2), 50\% (A3) and 75\% (A4) as the main plot, while intercropping (2 levels), as the sub plot. The results showed that the Current Annual Increment (CAI) of diameter at breast height (CAI DBH), volume/tree (CAI vol/tree) and volume/hectare (CAI vol/ha) of stands gave a significant positive response to thinning intensity treatment. CAI DBH one year after thinning were $0.79 \mathrm{~cm}, 1.47 \mathrm{~cm}$, and $2.46 \mathrm{~cm}$; increased by $32 \%, 145 \%$ and $310 \%$ at the thinning intensity of $25 \%, 50 \%$ and $75 \%$ when they compared with the control $(0.59 \mathrm{~cm})$. CAI vol/ha of stand in the first year, namely $11.88 \mathrm{~m}^{3} / \mathrm{ha}, 14.04 \mathrm{~m}^{3} / \mathrm{ha}$, and $16.78 \mathrm{~m}^{3} / \mathrm{ha}$ or with an increase of 9\%, 29\% and 54\% respectively at an intensity of $25 \%, 50 \%$ and $75 \%$ compared to the control.
\end{abstract}

\section{Keywords: silvicultural treatnent, stand density, current annual increment}

\begin{abstract}
ABSTRAK
Penjarangan merupakan salah satu tindakan silvikultur untuk meningkatkan pertumbuhan dan kualitas tegakan tinggal. Penelitian ini bertujuan untuk mengetahui respon pertumbuhan jati klon terseleksi terhadap intensitas penjarangan dan tumpang sari. Metode penelitian menggunakan Rancangan Acak Lengkap Berblok (RALB) faktorial dengan intensitas penjarangan (4 level): $0 \%$ (kontrol=A1), 25\% (A2), 50\% (A3) dan 75\% (A4) sebagai plot utama, sedangkan tumpang sari (2 level) yaitu dengan tumpang sari (B1) dan tanpa tumpang sari (B2) sebagai sub plotnya. Hasil penelitian menunjukkan bahwa Current Annual Increment (CAI) parameter diameter setinggi dada (CAI DBH), volume individu pohon (CAI vol/tree) dan volume per hektar (CAI vol/ha) tegakan tinggal memberikan respon positif secara signifikan terhadap perlakuan intensitas penjarangan. CAI DBH satu tahun setelah penjarangan sebesar $0,79 \mathrm{~cm}, 1,47 \mathrm{~cm}$, dan $2,46 \mathrm{~cm}$; meningkat $32 \%$, $145 \%$ dan $310 \%$ pada intensitas penjarangan $25 \%, 50 \%$ dan $75 \%$ bila dibandingkan dengan kontrol $(0,6 \mathrm{~cm})$. CAI vol/ha pada tahun pertama, yaitu sebesar $11,88 \mathrm{~m}^{3} / \mathrm{ha}, 14,04 \mathrm{~m}^{3} / \mathrm{ha}$, dan $16,78 \mathrm{~m}^{3} /$ ha atau dengan peningkatan sebesar $9 \%, 29 \%$ dan $54 \%$ masing-masing pada intensitas 25\%, 50\% dan 75\% dibanding kontrol. Gambaran diskusi dan kesimpulan secara singkat.
\end{abstract}

Kata kunci: tindakan silvikultur, kerapatan tegakan, riap tahunan berjalan

\section{PENDAHULUAN}

Jati (Tectona grandis L.f.) termasuk salah satu kayu berkualitas tinggi dengan kekuatan dan tekstur yang indah dari famili Verbenaceae. Daerah sebaran asli jati meliputi India, Laos,
Myanmar, dan Thailand (Kollert \& Cherubini, 2012). Persediaan kayu jati secara berkelanjutan dari hutan alam semakin menurun, sementara itu permintaan terus meningkat (Pandey \& Brown, 2000). Saat ini jati telah dikenal secara luas dan 
dikembangkan di banyak negara di dunia baik oleh pemerintah, swasta, maupun petani. Di seluruh dunia, hutan tanaman jati diperkirakan seluas 4,346 juta ha, sebagian besar (83\%) hutan tanaman jati tersebut ada di Asia (Kollert \& Cherubini, 2012). Di Indonesia luas hutan tanaman jati tercatat sekitar 1 juta hektar (Perhutani, 2014), angka tersebut adalah luasan yang hanya dikelola oleh perum Perhutani, belum termasuk hutan tanaman jati milik masyarakat. (Perhutani, 2020) menentukan kualitas pohon jati berdasarkan ukuran diameternya, yaitu sortimen A I dengan diameter 16-19 cm dengan nilai jual sampai $\mathrm{Rp}$. $2,8 \mathrm{juta} / \mathrm{m}^{3}$; sortimen A II (diameter 22-28 cm), A III (30-39 cm), dan A IV (40-49 cm) dengan nilai masing-masing sampai dengan Rp. 3,6 juta, Rp. 5,8 juta dan Rp. 7,5 per $\mathrm{m}^{3}$. Perlakuan silvikultur yang tepat akan mampu meningkatkan kualitas pohon jati sehingga dapat meningkatkan nilai jualnya (Pramono et al., 2010).

Dalam perdagangan kayu bulat di dunia, market share kayu jati di dunia kurang dari $2 \%$ dari total penjualan kayu bulat dari daerah tropis, tapi nilai kayunya yang tinggi membuat kayu jati menjadi komponen utama ekonomi bidang kehutanan bagi banyak negara tropis (Kollert \& Cherubini, 2012). Nilai jual kayu jati ditentukan oleh kualitas pohon yang dicirikan dengan ukuran diameter pohon, kelurusan batang, tinggi batang bebas cabang, dan ada tidaknya cacat kayu. Perlakuan silvikultur yang dapat dilakukan untuk meningkatkan kualitas kayu dan produktivitas hutan antara lain adalah penggunaan bibit bergenetik unggul, kerapatan tegakan dan pengontrolan kompetisi atau persaingan antar pohon dengan cara penjarangan (Fox, 2000).

Permintaan kayu jati yang tinggi menyebabkan penggunaan rotasi tebang yang relatif pendek yaitu 20-30 tahun. Rotasi pendek hanya dapat dipenuhi oleh tegakan jati dengan produktivitas tinggi, yaitu tegakan yang mempunyai pertumbuhan cepat dan kualitas kayu yang baik (Pandey \& Brown, 2000). Perum
Perhutani bekerja sama dengan Fakultas Kehutanan UGM melakukan penelitian dan pengujian menggunakan strategi pemuliaan pohon. Kerja sama tersebut dimulai sejak tahun 1980-an hingga tahun 2000-an dan telah berhasil melakukan koleksi plasma nutfah dari ratusan pohon plus dari seluruh sebaran jati di Indonesia baik di Jawa maupun luar Jawa. Hasil seleksi dengan uji keturunan dan uji klon di beberapa lokasi menunjukan bahwa famili unggul yang terseleksi dapat tumbuh baik pada berbagai tempat tumbuh. Hasil perbanyakan vegetatif famili unggul tersebut diberi nama Jati Plus Perhutani (JPP) (Na'iem et al., 2017). Keunggulan JPP antara lain pertumbuhan diameter dan tinggi yang cepat, bentuk batang yang lurus dan silindris, serta batang bebas cabang yang tinggi. Pertumbuhan JPP yang cepat menyebabkan ruang tumbuh cepat terisi sehingga menimbulkan kompetisi antar pohon untuk mendapatkan nutrisi, air dan sinar matahari meningkat (Sadono \& Silalahi, 2010). Pengontrolan kompetisi untuk meningkatkan kualitas tegakan dapat dilakukan dengan penjarangan (Fox, 2000).

Pusat Penelitian dan Pengembangan Hutan Perhutani bekerjasama dengan Fakultas Kehutanan UGM pada tahun 2004/2005 melakukan penanaman JPP dalam skala operasional di wilayah hutan Jawa Timur (3 KPH), Jawa Tengah (3 KPH) dan Jawa Barat (2 KPH). Salah satu areal penanaman tersebut adalah di petak 25-b, RPH Begal, BKPH Begal, KPH Ngawi, Perhutani Jawa Timur. Penanaman pada petak seluas 57,50 ha tersebut dilakukan dengan jarak tanam $6 \mathrm{~m} \times 2 \mathrm{~m}$. Tegakan jati tersebut, pada tahun 2016 telah berumur 11 tahun dan menunjukkan adanya struktur tajuk sudah saling bersentuhan dan saling menutupi. Keadaan ini diduga telah menyebabkan peningkatan persaingan antar individu pohon dalam ruang tumbuh untuk mendapatkan sinar matahari, air dan nutrisi yang selanjutnya dapat mengakibatkan pertumbuhan tegakan hutan menurun. Untuk mengurangi persaingan tersebut, maka perlu dilakukan pengaturan 
terhadap struktur vertikal tajuk dan struktur horisontal jarak antar individu pohon. Pengaturan struktur vertikal dan horisontal tegakan dapat dilakukan melalui tindakan silvikultur penjarangan terhadap tegakan jati tersebut (Fox, 2000).

Penjarangan merupakan tindakan yang secara sengaja mengurangi jumlah pohon pada suatu tegakan (Evans, 1992), yang secara mendasar mempengaruhi pertumbuhan, perkembangan, struktur dan hasil. Intensitas dan waktu penjarangan merupakan hal penting untuk mencapai tujuan silvikultur yang diinginkan. Penjarangan dengan intensitas yang tepat dapat memperpanjang pengaruh penjarangan sehingga dapat meningkatkan kualitas tegakan tinggal melalui pertumbuhan diameter yang cepat. Apabila tindakan silvikultur penjarangan dilakukan pada waktu yang tepat dapat menciptakan pertumbuhan tegakan seperti yang diharapkan dan mencegah terjadinya stagnasi pertumbuhan (Nyland et al., 2001).

Produktivitas lahan di Indonesia yang mempunyai iklim tropis dinilai masih rendah, salah satu sistem pertanaman yang dapat dijadikan solusi masalah ini adalah sistem agroforestri atau tumpang sari (Suryani \& Dariah, 2012). Sistem penanaman jati di Jawa umumnya dilakukan dengan tumpang sari yang dikombinasikan dengan tanaman pertanian/semusim di dalam satu area (Pramono et al., 2010). Dalam sistem tumpang sari, di samping mendapatkan hasil kayu, juga dapat diperoleh hasil jangka pendek, berupa panen dari tanaman yang ditumpang sarikan, seperti jagung, kacang tanah, dan empon-empon (Iftitah \& Haryono, 2018). Kelebihan metode tumpang sari yaitu pemanfaatan lahan kosong di antara tanaman utama sehingga dapat meningkatkan efektifitas pemanfaatan sinar matahari, air serta nutrisi tanah, dan menghalangi pertumbuhan gulma (Herlina, 2011). Pada saat perlakuan penjarangan dilakukan maka terdapat ruang tumbuh bagi tegakan tinggal yang dapat dimanfaatkan untuk tanaman tumpang sari. Tumpang sari pada tegakan yang sudah cukup tua sebaiknya menggunakan jenis tanaman yang tahan terhadap naungan. Empon-empon merupakan salah satu jenis tumbuhan bawah yang mampu bertahan hidup dan tumbuh di bawah tegakan (Guntara, 2013).

Penelitian tindakan silvikultur penjarangan dan tumpang sari pada tegakan JPP umur di atas 10 tahun relatif belum banyak dilakukan. Untuk itu maka penelitian intensitas tindakan silvikultur penjarangan yang dikombinasikan dengan tanaman tumpang sari (temulawak (Curcuma sp) jenis empon-empon) menjadi penting untuk dilakukan. Tujuan penelitian ini adalah untuk mengetahui respons pertumbuhan tegakan tinggal terhadap perlakuan intensitas penjarangan dan tanaman tumpang sari pada tegakan JPP umur 11 tahun.

\section{BAHAN DAN METODE}

\section{A. Lokasi penelitian}

Penelitian dilakukan pada periode Juni 2016 - Juni 2018 di area Perum Perhutani yaitu petak 25 b RPH Begal, BKPH Begal, KPH Ngawi, Jawa Timur. Titik koordinat lokasi penelitian dengan sistem Universal Transverse Mercator (UTM) adalah $49(527753.00 \mathrm{~m} \mathrm{E} \mathrm{-}$ $529273.00 \mathrm{~m}$ E dan $9173580.00 \mathrm{~m} \quad \mathrm{~S}$ $9174586.00 \mathrm{~m} \mathrm{~S}$ ) (Gambar 1).

Lokasi penelitian mempunyai curah hujan $1.436 \mathrm{~mm} / \mathrm{th}$, dengan hari hujan 104 hari/th, ketinggian tempat atau elevasi berkisar 179 197 mdpl. Topografi tanah datar - landai dengan kemiringan 5-10 \%. Sifat fisik tanah antara lain; solum tanah tipis $(15 \mathrm{~cm})$ hingga tebal $(>100$ $\mathrm{cm}$ ), warna tanah mulai dari hitam (black), 10 YR 2/1 hingga coklat tua kelabu (dark grayish brown), dengan nilai 10 YR 4/2, dengan tekstur lempungan (clay) dengan kandungan pasir $15,95 \%$, debu $34,45 \%$, lempung $49,50 \%$. Sedangkan karakter kimia tanah yaitu kemasaman tanah $\left(\mathrm{pH} \mathrm{H}_{2} \mathrm{O}\right)$ 5,85 (agak masam), $\mathrm{C}$ organic $1,23 \%, \mathrm{~N}$ total $0,11 \%, \mathrm{P}$ tersedia $(8,25 \mathrm{ppm}), \mathrm{K}$ tersedia sangat rendah $(0,08$ ppm), Ca tersedia tinggi (11,32 ppm), $\mathrm{Mg}$ tersedia $(3,99 \mathrm{ppm})$ dan kapasitas pertukaran 
kation (KPK) sebesar 21,87 me/100 g (Prehaten et al., 2018).

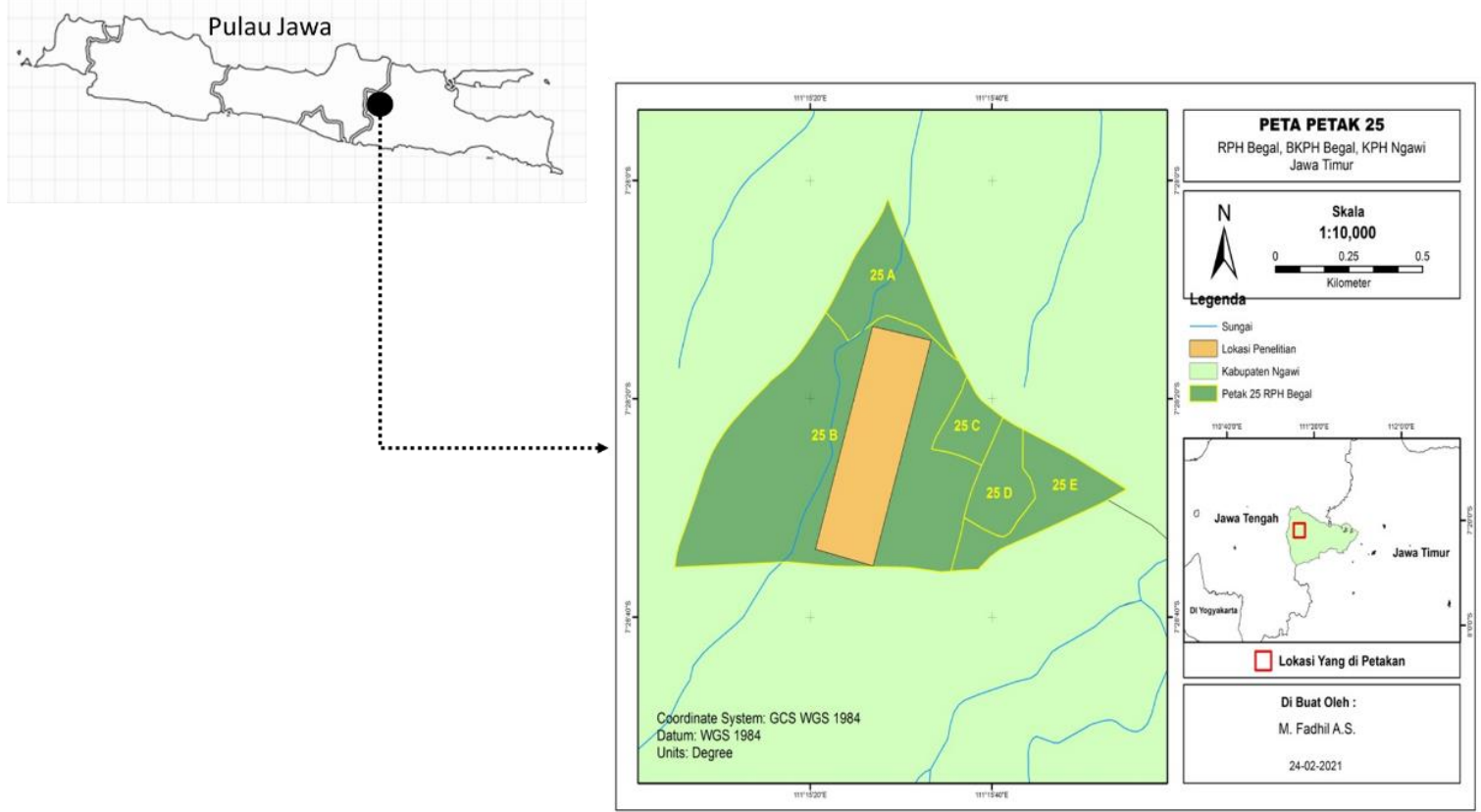

Gambar 1. Lokasi penelitian di Petak 25b, RPH Begal, BKPH Begal, KPH Ngawi, Jawa Timur

\section{B. Metode}

\section{Rancangan penelitian}

Bahan tanaman adalah tanaman JPP berasal dari stek pucuk (klon) yang ditanam pada tahun 2005 (umur 11 tahun), dengan jarak tanam $6 \mathrm{~m} \times 2 \mathrm{~m}$. Tegakan JPP dijarangi pada bulan Mei 2016 dengan beberapa intensitas yaitu $0 \%$ (kontrol), $25 \%, 50 \%$ dan $75 \%$.

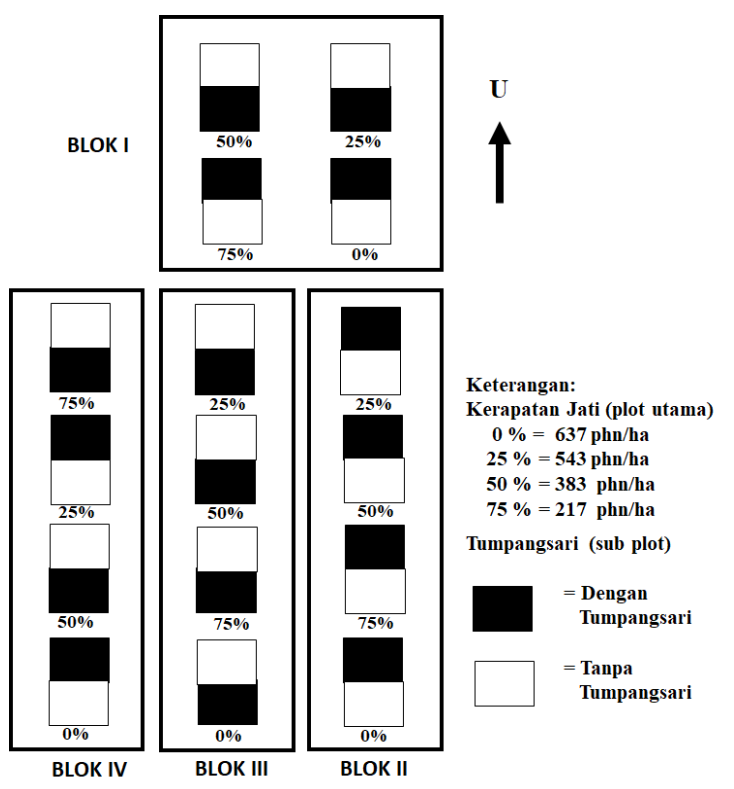

Gambar 2. Desain penelitian
Rancangan yang digunakan adalah faktorial Randomized Complete Block Design (RCBD), plot utama adalah perlakuan penjarangan (A), dengan 4 level intensitas penjarangan $(\mathrm{A} 1=0 \%(\mathrm{kontrol}), \mathrm{A} 2=25 \%, \mathrm{~A} 3$ $=50 \%$ dan $\mathrm{A} 4=75 \%$ ), dengan jumlah pohon secara berturut turut adalah $637,543,383$, dan 217 pohon/ha, sedangkan sub plot adalah perlakuan tumpang sari, dengan 2 level perlakuan yaitu dengan tumpang sari temulawak (Curcuma xanthorrhiza) (B1) dan tanpa tumpang sari (B2) (Gambar 2).

\section{Analisis Data}

Pengukuran DBH dan tinggi pohon dilakukan sebanyak tiga kali yaitu segera setelah penjarangan pada Juni 2016 ( $\mathrm{T} 0=$ baseline data), Juni tahun 2017 (T1) dan Juni 2018 (T2), atau 1 dan 2 tahun setelah penjarangan. Respons pertumbuhan DBH (CAI DBH) dan tinggi (CAI $\mathrm{H})$ pohon pada tahun pertama setelah penjarangan dilakukan dengan melakukan pengurangan $\mathrm{DBH}$ dan tinggi pada $\mathrm{T} 1$ dengan T0; sedang pertumbuhan pada tahun ke-dua melalui pengurangan $\mathrm{T} 2$ dengan $\mathrm{T} 1$. Volume $(\mathrm{V}$, $\mathrm{m}^{3}$ ) untuk setiap individu pohon (CAI vol/tree) dihitung dengan menggunakan persamaan (Perez, 2008): V $=(-0,0884+0,0297 * \mathrm{DBH})^{2}$. 
Volume per hektar (CAI vol/ha) diperoleh dari volume individu pohon (CAI vol/tree) dikalikan jumlah pohon per hektar, dengan formulasi: $h V=t V * h N$, di mana $h V=$ Volume/ha, $t V=$ Volume per pohon dan $h N=$ jumlah pohon/ha.

Perbedaan persentase DBH, tinggi, volume/pohon dan volume/hektar perlakuan penjarangan dilakukan melalui pengurangan nilai pengukuran pada plot penjarangan $(25 \%$, $50 \%$ dan $75 \%$ ) dengan kontrol, diformulasikan: $\frac{b-a}{a}: 100 \%$, di mana $b=$ nilai parameter $\mathrm{DBH}$, tinggi, vol/tree, vol/ha pada plot penjarangan, sedangkan a = nilai DBH, tinggi, vol/tree, vol/ha pada plot kontrol.

Perbedaan persentase DBH, tinggi, volume/pohon dan volume/hektar 1 tahun dan 2 tahun setelah penjarangan, dilakukan melalui pengurangan nilai pengukuran pada plot penjarangan $(0 \%, 25 \%, 50 \%$ dan $75 \%)$ tahun pertama dengan tahun kedua; diformulasikan: $\frac{T 1-T 2}{T 1} \times 100 \%$, di mana $T 1=$ nilai parameter DBH, tinggi, vol/tree, vol/ha pada pengukuran tahun pertama, sedangkan $T 2=$ nilai $\mathrm{DBH}$, tinggi, vol/tree, vol/ha pada tahun kedua.
Data yang diperoleh dianalisis menggunakan software SPSS 20.2 dengan menggunakan Analisis Varians (ANOVA) dengan rancangan Factorial Randomized Completely Block Design (RCBD Faktorial). Data yang dianalisis adalah pertumbuhan DBH (CAI DBH), tinggi (CAI H), volume per pohon (CAI vol/tree) dan volume per hektar (CAI $\mathrm{vol} / \mathrm{ha}$ ) setelah 1 dan 2 tahun penjarangan. Perbedaan antar perlakuan dianalisis dengan uji lanjut Duncan Multiple Range Test (DMRT) pada taraf siginifikansi $\alpha 5 \%$.

\section{HASIL DAN PEMBAHASAN}

\section{A. Pertumbuhan DBH dan tinggi pohon}

Hasil ANOVA terhadap pertumbuhan DBH dan tinggi tanaman setelah penjarangan tahun pertama dan tahun kedua (Tabel 1) menunjukkan bahwa faktor intensitas penjarangan berpengaruh sangat signifikan pada taraf $1 \%$, sedang faktor tumpang sari dan interaksi intensitas penjarangan dan tumpang sari tidak berpengaruh signifikan pada taraf $5 \%$.

Tabel 1. Anova perlakuan penjarangan dan tumpang sari terhadap pertumbuhan DBH dan tinggi

\begin{tabular}{|c|c|c|c|c|c|c|c|c|c|}
\hline \multirow{3}{*}{$\begin{array}{l}\text { Sumber } \\
\text { variasi }\end{array}$} & \multirow{3}{*}{$\mathrm{db}$} & \multicolumn{4}{|c|}{ Diameter } & \multicolumn{4}{|c|}{ Tinggi } \\
\hline & & \multicolumn{2}{|c|}{ Tahun pertama } & \multicolumn{2}{|c|}{ Tahun kedua } & \multicolumn{2}{|c|}{ Tahun pertama } & \multicolumn{2}{|c|}{ Tahun kedua } \\
\hline & & F Hit & $\mathrm{P}>\mathrm{F}$ & F Hit & $\mathrm{P}>\mathrm{F}$ & F Hit & $\mathrm{P}>\mathrm{F}$ & F Hit & $\mathrm{P}>\mathrm{F}$ \\
\hline Blok & 3 & 1,42 & $0,27^{\mathrm{ns}}$ & 1,28 & $0,31^{\mathrm{ns}}$ & 1,83 & $0,17^{\mathrm{ns}}$ & 2,25 & $0,11^{\mathrm{ns}}$ \\
\hline Penjarangan & 3 & 71,86 & $0,00 * *$ & 171,80 & $0,00 * *$ & 16,27 & $0,00 * *$ & 3,44 & 0,03 \\
\hline Tumpang sari & 1 & 0,38 & $0,55^{\mathrm{ns}}$ & 0,36 & $0,55^{\mathrm{ns}}$ & 0,03 & $0,86^{\mathrm{ns}}$ & 2,5 & $0,13^{\mathrm{ns}}$ \\
\hline $\begin{array}{l}\text { Penjarangan } \mathrm{x} \\
\text { Tumpang sari }\end{array}$ & 3 & 0,09 & $0,96^{\mathrm{ns}}$ & 0,94 & $0,44^{\mathrm{ns}}$ & 0,82 & $0,50^{\mathrm{ns}}$ & 0,4 & $0,75^{\mathrm{ns}}$ \\
\hline
\end{tabular}

Keterangan: $* *=$ Berbeda sangat signifikan pada taraf kepercayaan $1 \%$; $*$ Berbeda signifikan pada taraf kepercayaan 5\%; $\mathrm{ns}=$ Tidak berbeda signifikan pada taraf kepercayaan $5 \%$

Pertumbuhan DBH tahunan (current annual increment DBH/CAI DBH) dalam tahun pertama setelah penjarangan untuk intensitas penjarangan $0 \%, 25 \%, 50 \%$ dan $75 \%$ berturut turut sebesar $0,60 \mathrm{~cm}, 0,79 \mathrm{~cm}, 1,47 \mathrm{~cm}$ dan 2,46 cm (Gambar 3). Hasil uji DMRT juga menunjukkan bahwa intensitas penjarangan juga memberikan hasil yang signiflkan terhadap CAI DBH dalam tahun kedua setelah penjarangan. CAI DBH pada tahun kedua menunjukkan penurunan yang nyata dibandingkan dengan tahun pertama yaitu masing-masing sebesar 0,24 $\mathrm{cm}, 0,37 \mathrm{~cm}, 0,57 \mathrm{~cm}, 1,33 \mathrm{~cm}$. Perlakuan penjarangan pada tahun pertama dapat meningkatkan pertumbuhan DBH sebesar 310\%, $145 \%$ dan $32 \%$ masing-masing untuk tingkat penjarangan $75 \%, \quad 50 \%$ dan $25 \%$ jika dibandingkan dengan kontrol (0\%). Persentase CAI DBH dalam tahun kedua setelah penjarangan memberikan hasil yang serupa 
seperti pada tahun pertama, yaitu dengan peningkatan sebesar $454 \%, 137 \%$ dan $54 \%$ masing-masing untuk intensitas penjarangan
$75 \%, 50 \%$ dan $25 \%$ jika dibandingkan dengan kontrol (0\%).

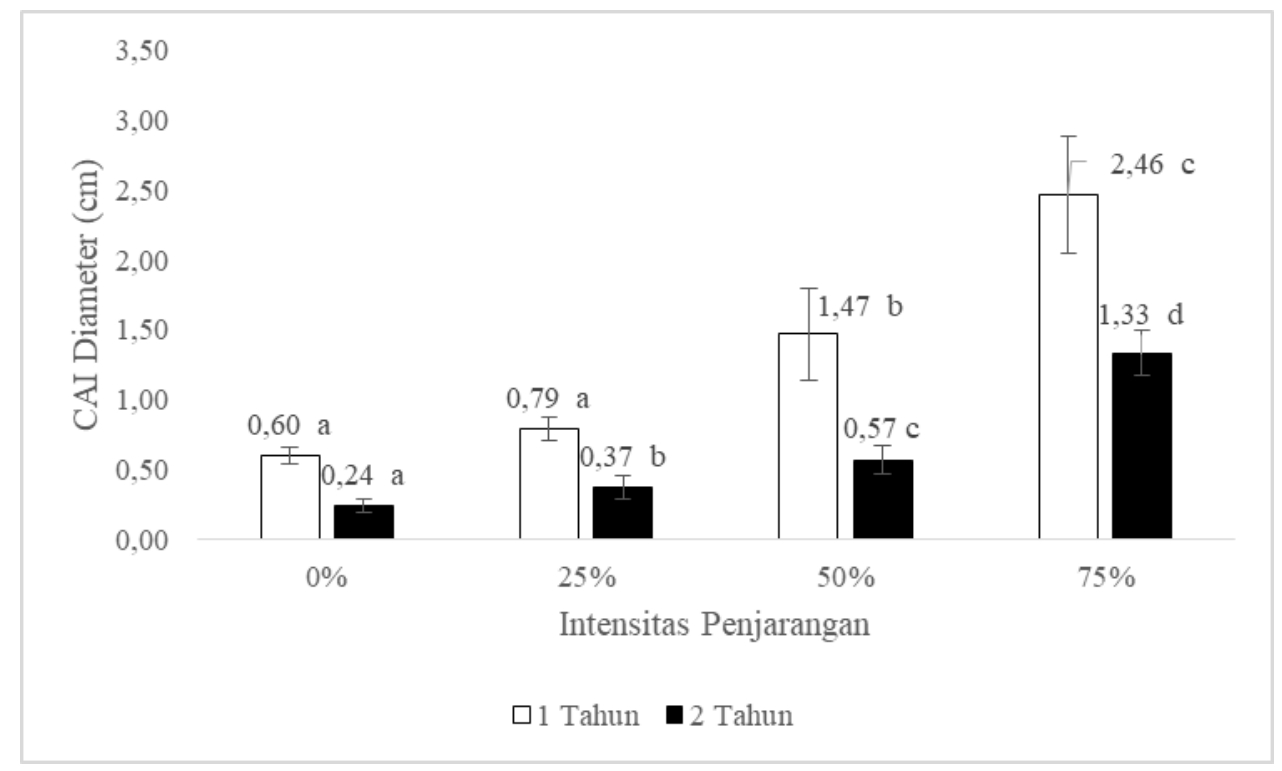

Gambar 3. Pertumbuhan diameter (CAI DBH) JPP pada berbagai perlakuan intensitas penjarangan

Terjadi penurunan CAI DBH dalam tahun kedua setelah penjarangan dibandingan pada tahun pertama, yaitu sebesar 47\%, 39\% dan 54\% masing-masing untuk intensitas penjarangan $25 \%, 50 \%$ dan $75 \%$. Hasil penelitian menunjukkan bahwa pertumbuhan DBH memberikan respons yang besar dalam tahun pertama setelah penjarangan, tetapi mengalami penurunan yang signifikan dalam tahun kedua setelah penjarangan. Hasil penelitian menunjukkan bahwa semakin besar intensitas penjarangan maka semakin besar pertumbuhan DBH tanaman JPP. Keadaan ini sama dengan hasil penelitian yang dilakukan di Pagoh, semenanjung Malaysia oleh Yahya et al., (2011) di mana semakin besar tingkat intenitas penjarangan, maka pertambahan pertumbuhan semakin besar. Pérez dan Kanninen (2005) menemukan bahwa terjadi pengaruh yang signifikan terhadap pertumbuhan $\mathrm{DBH}$, dimana pertumbuhan yang paling kecil terjadi pada perlakuan tanpa penjarangan. Hasil serupa dilaporkan oleh Budiadi et al., (2017), dimana terjadi penurunan pertumbuhan tanaman jati bergenetik unggul setelah 3 tahun penjarangan di Hutan Pendidikan Wanagama Universitas Gadjah Mada. Penurunan pertumbuhan diameter setelah penjarangan terjadi karena tajuk kembali menutup dan persaingan mendapatkan sinar matahari, nutrisi dan air tanah kembali terjadi secara intens (Budiadi et al., 2017; Pérez \& Kanninen, 2005; Yahya et al., 2011).

Hasil Uji DMRT seperti yang disajikan pada Gambar 4 menunjukkan bahwa intensitas penjarangan $75 \%$ memberikan hasil yang signifikan dibandingkan dengan intensitas penjarangan $0 \%$, 25\% dan $50 \%$ pada tahun pertama setelah penjarangan terhadap tinggi tanaman. Delta tinggi (CAI H) tanaman setelah tahun pertama, untuk penjarangan $0 \%$ adalah $25 \%, 50 \%$ dan $75 \%$ berturut turut adalah 0,72 $\mathrm{m}, 0,74 \mathrm{~m}, 0,73 \mathrm{~m}$ dan $1,28 \mathrm{~m}$. Sementara untuk CAI $\mathrm{H}$ dalam tahun kedua adalah sebesar 0,29 $\mathrm{m}, 0,45 \mathrm{~m}, 0,42 \mathrm{~m}, 0,58 \mathrm{~cm}$. Penjarangan dengan intensitas yang tinggi (75\%) menghasilkan delta tinggi (CAI H) terbesar, hal yang sama ditemukan oleh Kurniawan et al., (2011). Delta tinggi (CAI H) yang besar pada intensitas penjarangan tinggi diakibatkan oleh berkurangnya jumlah pohon pada tapak tersebut sehingga mengakibatkan jumlah nutrisi, air dan sinar matahari yang dapat akses meningkat (Noordwijk et al., 2015). 


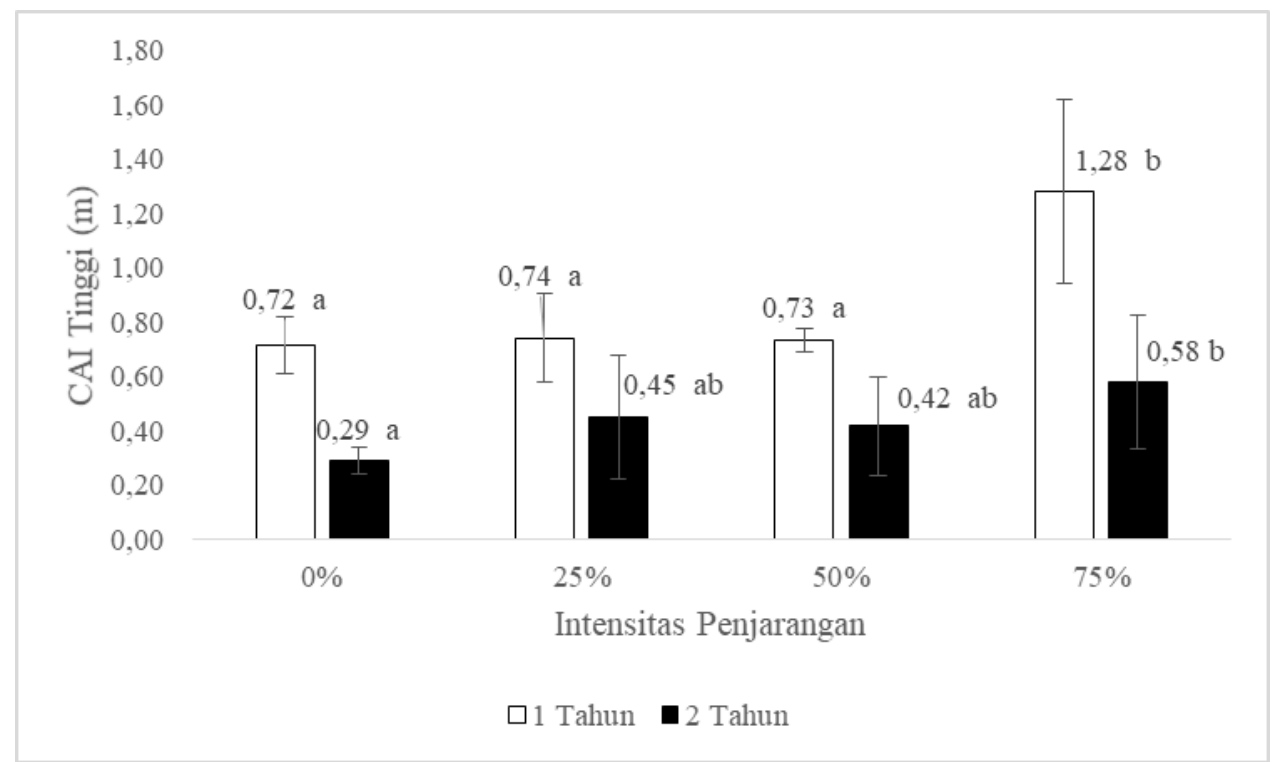

Gambar 4. Pertumbuhan tinggi (CAI H) tanaman pada berbagai perlakuan intensitas penjarangan

\section{B. Pertumbuhan volume per pohon dan tegakan per hektar}

Hasil ANOVA terhadap pertumbuhan volume per pohon (CAI vol/tree) dan per hektar (CAI vol/ha) tahun pertama dan tahun kedua setelah penjarangan menunjukkan bahwa faktor intensitas penjarangan berpengaruh sangat signifikan pada taraf $1 \%$. Faktor tumpang sari dan interaksi intensitas penjarangan dan tumpang sari tidak berpengaruh signifikan pada taraf 5\% (Tabel 4).

Tabel 4. Anova perlakuan penjarangan dan tumpang sari terhadap pertumbuhan volume per pohon dan volume tegakan per hektar

\begin{tabular}{|c|c|c|c|c|c|c|c|c|c|}
\hline \multirow{3}{*}{ Sumber variasi } & \multirow{3}{*}{$\mathrm{db}$} & \multicolumn{4}{|c|}{ Volume per pohon } & \multicolumn{4}{|c|}{ Volume tegakan per hektar } \\
\hline & & \multicolumn{2}{|c|}{ Tahun pertama } & \multicolumn{2}{|c|}{ Tahun kedua } & \multicolumn{2}{|c|}{ Tahun pertama } & \multicolumn{2}{|c|}{ Tahun kedua } \\
\hline & & F Hit & $\mathrm{P}>\mathrm{F}$ & F Hit & $\mathrm{P}>\mathrm{F}$ & F Hit & $\mathrm{P}>\mathrm{F}$ & F Hit & $\mathrm{P}>\mathrm{F}$ \\
\hline Blok & 3 & 1,28 & $0,31^{\mathrm{ns}}$ & 0,72 & $0,55^{\mathrm{ns}}$ & 0,60 & $0,63^{\mathrm{ns}}$ & 0,68 & $0,58^{\mathrm{ns}}$ \\
\hline Penjarangan & 3 & 83,35 & $0,00 * *$ & 132,18 & $0,00 * *$ & 6,11 & $0,04 *$ & 13,50 & $0,00 * *$ \\
\hline Tumpang sari & 1 & 0,14 & $0,71^{\mathrm{ns}}$ & 0,50 & $0,49^{\text {ns }}$ & 0,18 & $0,67^{\mathrm{ns}}$ & 0,53 & $0,48^{\mathrm{ns}}$ \\
\hline $\begin{array}{l}\text { Penjarangan } \mathrm{x} \\
\text { Tumpang sari }\end{array}$ & 3 & 0,06 & $0,98^{\text {ns }}$ & 0,92 & $0,45^{\mathrm{ns}}$ & 0,57 & $0,62^{\text {ns }}$ & 0,42 & $0,74^{\mathrm{ns}}$ \\
\hline
\end{tabular}

Keterangan: $* *=$ Berbeda sangat signifikan pada taraf kepercayaan $1 \%$; $*$ Berbeda signifikan pada taraf kepercayaan 5\%; $\mathrm{ns}=$ Tidak berbeda signifikan pada taraf kepercayaan $5 \%$

Hasil uji lanjut DMRT menunjukkan bahwa intensitas penjarangan $75 \%$ memberikan hasil pertumbuhan volume/pohon yang tertinggi dan signifikan dibandingkan dengan intensitas penjarangan 50\%, 25\% dan 0\% (Gambar 5). CAI volume/pohon (CAI vol/tree) dalam tahun pertama setelah penjarangan untuk intensitas penjarangan $0 \%, 25 \%, 50 \%$ dan $75 \%$ berturut turut sebesar $0,020 \mathrm{~cm}^{3}, 0,028 \mathrm{~cm}^{3}, 0,050 \mathrm{~cm}^{3}$ dan $0,104 \mathrm{~cm}^{3}$. CAI vol/tree dalam tahun kedua setelah penjarangan dengan intensitas $0 \%, 25 \%$, $50 \%$ dan $75 \%$ menunjukkan penurunan yang nyata dibandingkan dengan tahun pertama yaitu masing-masing sebesar $0,009 \mathrm{~cm}^{3}, 0,014 \mathrm{~cm}^{3}$, $0,021 \mathrm{~cm}^{3}$, dan $0,062 \mathrm{~cm}^{3}$. Perlakuan penjarangan pada tahun pertama dapat meningkatkan pertumbuhan CAI vol/tree sebesar $420 \%, 150 \%$ dan $40 \%$ masing-masing untuk tingkat penjarangan $75 \%, 50 \%$ dan $25 \%$ dibandingkan dengan kontrol (0\%). Walaupun CAI vol/tree mengalami penurunan yang signifikan dalam tahun kedua setelah penjarangan, tetapi persentase pertumbuhan volume/pohon masih memberikan hasil yang 
pertumbuhan yang tinggi, yaitu sebesar $589 \%$, $133 \%$ dan $55 \%$ masing-masing untuk tingkat penjarangan $75 \%, 50 \%$ dan $25 \%$ dibandingkan dengan kontrol $(0 \%)$. Terjadi penurunan CAI vol/tree dalam tahun kedua setelah penjarangan dibandingan tahun pertama, yaitu sebesar $50 \%$, $42 \%$ dan $60 \%$ masing-masing untuk intensitas $25 \%, 50 \%$ dan $75 \%$.

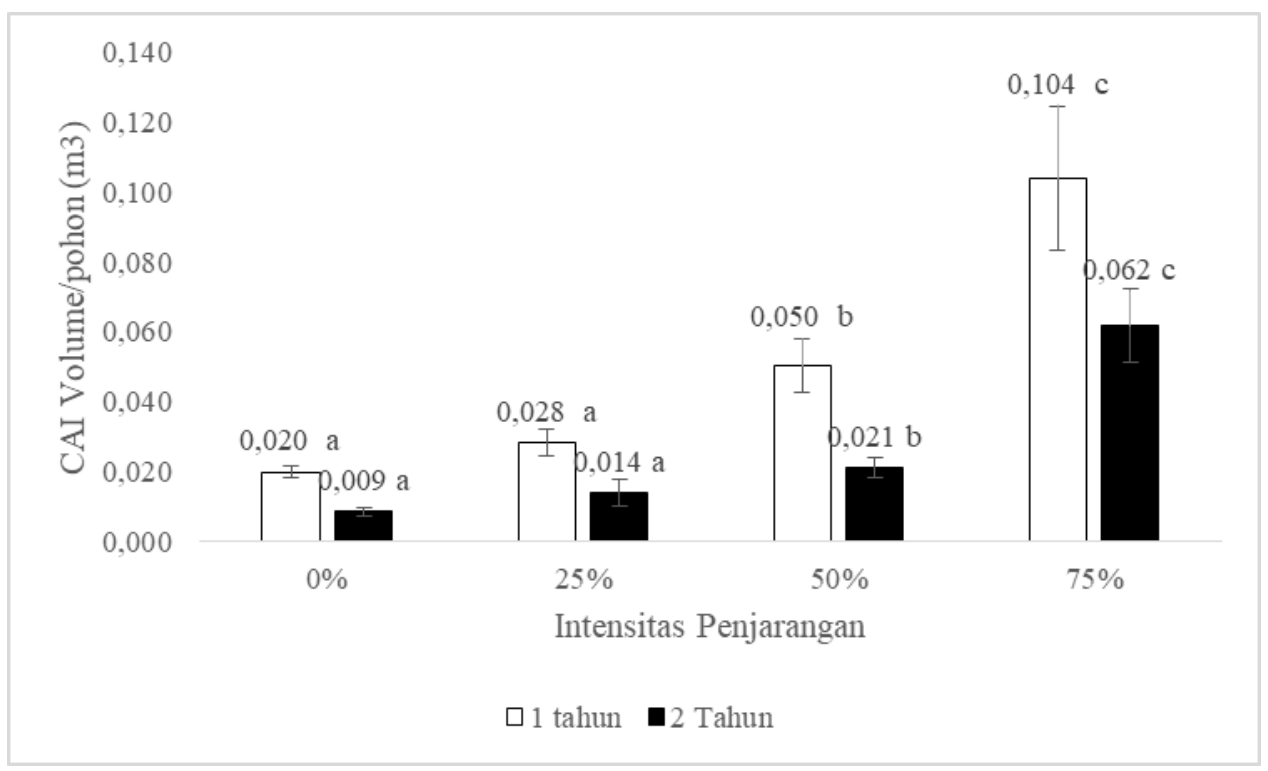

Gambar 5. Pertumbuhan volume/pohon (CAI vol/tree) pada berbagai perlakuan intensitas penjarangan.

Hasil Uji DMRT menunjukkan bahwa signifikan terhadap pertumbuhan volume intensitas penjarangan memberikan hasil yang tegakan/ha (Gambar 6).

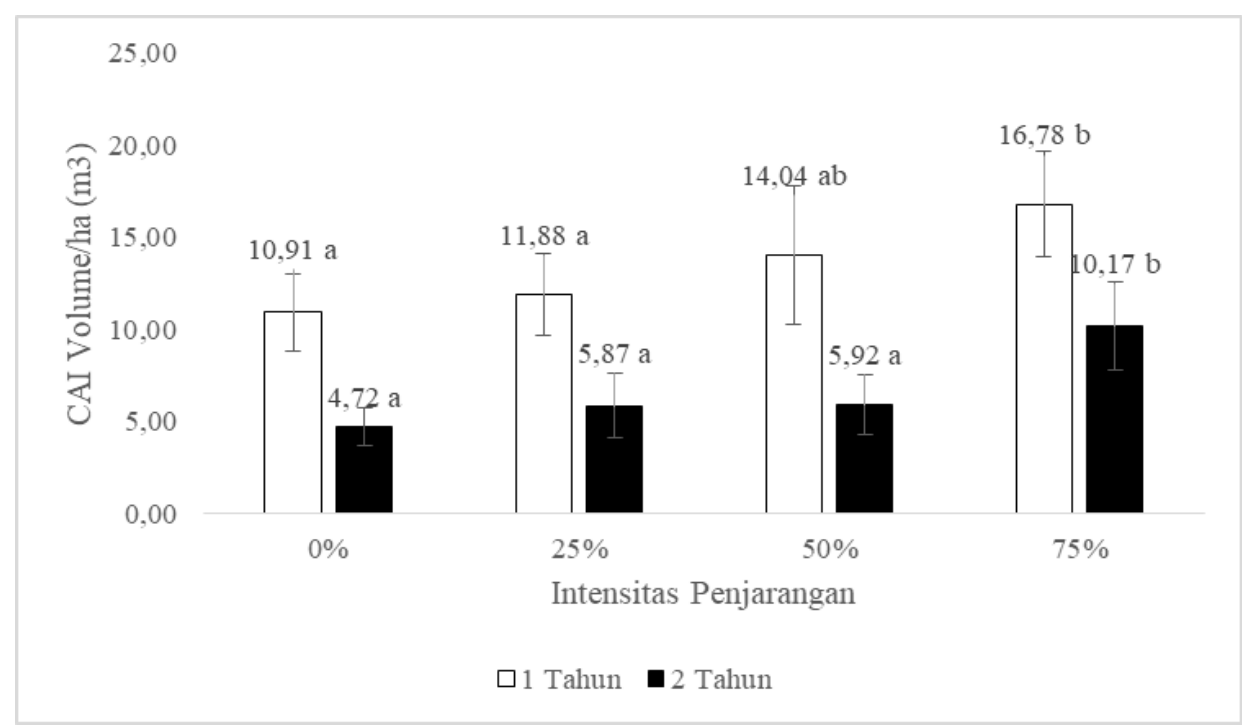

Gambar 6. Pertumbuhan volume tegakan per ha (CAI vol/ha) pada perlakuan intensitas penjarangan

CAI vol/ha dalam tahun pertama setelah penjarangan adalah $10,91 \mathrm{~m}^{3} / \mathrm{ha}, 11,88 \mathrm{~m}^{3} / \mathrm{ha}$, $14,04 \mathrm{~m}^{3} / \mathrm{ha}$ dan $16,78 \mathrm{~m}^{3} / \mathrm{ha}$ pada perlakuan penjarangan $0 \%, 25 \%, 50 \%$ dan $75 \%$. CAI $\mathrm{vol} / \mathrm{ha}$ tahun kedua setelah penjarangan adalah $4,72 \mathrm{~m}^{3} / \mathrm{ha}, 5,87 \mathrm{~m}^{3} / \mathrm{ha} 5,92 \mathrm{~m}^{3} / \mathrm{ha}$ dan 10,17 $\mathrm{m}^{3} /$ ha pada perlakuan penjarangan $0 \%, 25 \%$, $50 \%$ dan $75 \%$. Perlakuan penjarangan dapat meningkatkan pertumbuhan volume tegakan/hektar sebesar 54\%, 29\% dan 9\% pada tahun pertama dan $115 \%, 25 \%$, dan $24 \%$ pada pada tahun kedua masing-masing untuk tingkat penjarangan $75 \%, 50 \%$ dan $25 \%$ dibandingkan dengan kontrol $(0 \%)$. Terjadi penurunan CAI $\mathrm{vol} / \mathrm{ha}$ dalam tahun kedua setelah penjarangan sebesar 43\%, 49\%, 42\% dan $61 \%$ untuk 
intensitas $0 \%, 25 \%, 50 \%$ dan $75 \%$ dibandingan tahun pertama setelah penjarangan.

Hasil penelitian menunjukkan bahwa penjarangan pada tanaman jati yang relatif tua (umur 11 tahun) meningkatkan pertumbuhan DBH (CAI DBH), volume/pohon (CAI vol/tree) dan volume/hektar (CAI vol/ha) dengan sangat signifikan. Walaupun terjadi penurunan pertumbuhan ketiga parameter tersebut dengan semakin bertambahnya waktu dari saat penjarangan dilakukan (Budiadi et al., 2017; Pérez \& Kanninen, 2005; Yahya et al., 2011). Tanaman yang tidak diberikan perlakuan silvikultur penjarangan cenderung tidak mengalami pertumbuhan ketiga parameter secara signifikan. Keadaan ini disebabkan karena terbatasnya ruang tumbuh dan terjadi persaingan yang intens untuk memperoleh sinar matahari, air dan nutrisi yang dibutuhkan untuk pertumbuhan (Noordwijk et al., 2015). Namun, hasil penelitian lain juga menemukan bahwa penjarangan jati dengan intensitas $40 \%$, hanya meningkatkan keliling batang sebesar $11 \%$ (Pramono et al., 2010). Keadaan ini serupa dengan laporan Smith et al., (2016), di mana penjarangan awal (umur 6 tahun) sampai dengan intensitas $57 \%$ hanya memberikan pengaruh yang kecil terhadap pertumbuhan whitewood (Endospermum medullosum) di Vanuatu.

Perlakuan tumpang sari serta interaksi antara perlakuan penjarangan dan tumpang sari tidak memberikan pengaruh yang signifikan terhadap CAI DBH, CAI H, CAI vol/tree dan CAI vol/ha baik pada satu tahun maupun dua tahun setelah penjarangan. CAI DBH pada tahun pertama dan kedua setelah penjarangan masingmasing sebesar $1,30 \mathrm{~cm}$ dan $0,64 \mathrm{~cm}$ pada perlakuan tumpang sari, sedang pada perlakuan tanpa tumpang sari adalah $1,36 \mathrm{~cm}$ dan $0,62 \mathrm{~cm}$. CAI vol/tree pada tahun pertama dan kedua setelah penjarangan masing-masing sebesar $0,5135 \mathrm{~cm}^{3}$ dan sebesar $0,0271 \mathrm{~cm}^{3}$ pada perlakuan tumpang sari, sedang pada perlakuan tanpa tumpang sari adalah $0,4978 \mathrm{~cm}^{3}$ dan $0,0256 \mathrm{~cm}^{3}$. CAI vol/ha tahun pertama dan kedua setelah penjarangan sebesar $13,63 \mathrm{~m}^{3} / \mathrm{ha}$ dan sebesar $6,91 \mathrm{~m}^{3} /$ ha pada perlakuan tumpang sari, sedang pada perlakuan tanpa tumpang sari adalah $13,17 \mathrm{~m}^{3} / \mathrm{ha}$ dan $6,43 \mathrm{~m}^{3} / \mathrm{ha}$. Kegiatan tumpang sari tidak memberikan pengaruh yang signifikan diduga karena kegiatan tersebut tidak menyumbang faktor-faktor yang dapat meningkatkan pertumbuhan tanaman jati yang telah tua. Hubungan keberadaan tanaman tumpang sari dan tanaman pokok (pohon) tidak memberikan pengaruh baik positif maupun negatif terhadap pertumbuhan pohon jati JPP (Noordwijk et al., 2015). Beberapa persyaratan yang perlu diperhatikan untuk mendapatkan keberhasilan sistem tumpangsari adalah pemilihan jenis tanaman semusim dan manajemen yang tepat. Jenis dan karakter tanaman semusim yang baik untuk mendukung tanaman pokok jati berusia lanjut adalah tumbuhan bawah yang bersifat toleran terhadap naungan, misalnya temu lawak, kunyit, jahe, garut, talas dan porang (Prehaten et al., 2021) Sedangkan manajemen dan perlakuan silvikultur yang tepat pada sistem tumpangsari diantaranya adalah dengan memperhatikan waktu tanam dan pemupukan yang tepat, serta adanya perlakuan pemangkasan dan penjarangan (Warman \& Kristiana, 2018).

Hasil penelitian ini menunjukkan bahwa penjarangan sebagai tindakan pemeliharaan tegakan wajib dilaksanakan untuk meningkatkan pertumbuhan dan kualitas tegakan tinggal. Penjarangan yang tepat untuk jati JPP umur 11 tahun dengan jarak tanam $6 \mathrm{~m} \times 2 \mathrm{~m}(600-800$ pohon/ha) adalah penjarangan keras (50\%) dan sangat keras $(75 \%)$ karena kedua penjarangan ini menghasilkan pertumbuhan (DBH, Vol/Pohon, dan Vol/ha) tegakan tinggal yang signifikan dibandingkan kontrol dan penjarangan lemah (25\%). Rekomendasi untuk penelitian selanjutnya adalah pengukuran pertumbuhan tegakan tinggal perlu dilakukan secara time series untuk menentukan waktu yang tepat bagi penjarangan berikutnya dan penelitian penjarangan pada kondisi tapak dan umur tegakan jati yang berbeda. 


\section{KESIMPULAN}

Tegakan tinggal klon jati terseleksi umur 11 tahun memberikan respon pertumbuhan yang positif sangat nyata terhadap perlakuan penjarangan, khususnya pada intensitas penjarangan keras $(50 \%)$ dan sangat keras (75\%); sedangkan terhadap perlakuan tumpang sari, tegakan tinggal tidak memberikan respon pertumbuhan yang nyata. Penelitian mengenai respon pertumbuhan tegakan tinggal masih perlu dilanjutkan untuk dapat menentukan waktu yang tepat bagi tindakan penjarangan berikutnya.

\section{UCAPAN TERIMA KASIH}

Penelitian ini merupakan bagian dari penelitian disertasi Muhammad Fadhil A.S., dilaksanakan dengan dana dari Direktorat Riset dan Pengabdian Masyarakat, Direktorat Jenderal Penguatan Riset dan Pengembangan, Kementerian Riset, Teknologi, dan Pendidikan Tinggi tahun 2016. Penulis menyampaikan terimakasih kepada Pusat Penelitian dan Pengembangan Hutan Perhutani atas ijin penggunaan lokasi penelitian, bantuan dan kerjasamanya sehingga penelitian ini dapat diselesaikan.

\section{DAFTAR PUSTAKA}

Budiadi, Widiyatno, \& Ishii, H. (2017). Response of a clonal teak plantation to thinning and pruning in Java, Indonesia. Journal of Tropical Forest Science, 29(1), 44-53.

Evans, J. (1992). Plantation forestry in The Tropics (2nd ed). New York: Oxford University Press.

Fox, T. R. (2000). Sustained productivity in intensively managed forest plantations. Forest Ecology and Management, 138(1-3), 187202. 1127(00)00396-0 https://doi.org/10.1016/S0378-

Guntara. (2013). Agroforestri sebagai Alternatif Pemanfaatan Lahan Bawah Tegakan untuk Peningkatan Pendapatan Petani di Kabupaten Lumajang. Prosiding Seminar Agroforestri, 393-584.

Herlina. (2011). Kajian variasi jarak dan waktu tanam jagung manis dalam sistem tumpang sari jagung manis (Zea mays). Universitas Andalas, Padang.
Iftitah, S. N., \& Haryono, G. (2018). Pengkajian beberapa tanaman empon - empon di Desa Balesari Kecamatan Windusari Kabupaten Magelang. VIGOR:Jurnal Ilmu Pertanian Tropika Dan Subtropika, 3(1), 13-16.

Kollert, W., \& Cherubini, L. (2012). Teca - Mundo mercado, 3(January), 16-17.

Kurniawan, W. A., Prianto, S. D. A., \& Budiadi, B. (2011). Pengaruh Penjarangan dan Pruning Terhadap Pertumbuhan Tegakan Jati (Tectona Grandis Linn . F.) Unggul Selama 6 Bulan Di Wanagama 1 Gunungkidul. Skripsi Fakultas Kehutanan UGM, Yogyakarta Indonesia, Tidak dipublikasikan.

Na'iem, M., Indrioko, S., Widiyatno, W., \& Prehaten, D. (2017). Peranan teknologi silvikultur (SILIN) dan konservasi genetik dalam peningkatan produtivitas hutan jati rakyat di Pulau Jawa. Laporan Penelitian. Yogyakarta, Indonesia.

Noordwijk, M. van, Lawson, G., Hairiah, K., \& Wilson, J. (2015). Root distribution of trees and crops: competition and/or complementarity. Tree-Crop Interactions: Agroforestry in a Changing Climate, 221257.

https://doi.org/10.1079/9781780645117.0221

Nyland, R. D., Kenefic, L. S., Bohn, K. K., \& Stout, S. L. (2001). Silviculture. Concepts and applications. McGrawHill.

Pandey, D., \& Brown, C. (2000). Teak: A global overview. Unasylva, 51(201), 3-13.

Perez, D. (2008). Growth and volume equations developed from STEM analysis for Tectona grandis in Costa Rica. Journal of Tropical Forest Science, 20(1), 66-75.

Pérez, D., \& Kanninen, M. (2005). Effect of thinning on stem form and wood characteristics of teak (Tectona grandis) in a humid tropical site in Costa Rica. Silva Fennica, 39(2), 217-225. https://doi.org/10.14214/sf.385

Perhutani. (2014). Statistik Perum Perhutani 20092013. Perum Perhutani: Jakarta, Indonesia.

Perhutani. (2020). Toko Perhutani.

Pramono, A. A., Fauzi, M. A., Widyani, N., Heriansyah, I., \& Roshetko, J. M. (2010). Panduan Pengelolaan Hutan Jati Rakyat. CIFOR: Bogor, Indonesia.

Prehaten, D., Hardiwinoto, S., Na'iem, M., Supriyo, H., Widiyatno, W., \& Rodiana, D. (2021). Productivity of Arrowroots and Taro Grown Under Superior Teak Clones with Several Levels of Stand Density. Biosaintifika: Journal of Biology \& Biology Education, 
$13(1)$,

$51-57$.

https://doi.org/10.15294/biosaintifika.v13i1.2 6428

Prehaten, D., Indrioko, S., Hardiwinoto, S., Na'iem, M., \& Supriyo, H. (2018). Pengaruh Beberapa Karakteristik Kimia dan Fisika Tanah pada Pertumbuhan 30 Famili Uji Keturunan Jati (Tectona grandis) Umur 10 Tahun. Jurnal Ilmu Kehutanan, 12, 52-60. https://doi.org/10.22146/jik.34109

Sadono, R., \& Silalahi, M. L. (2010). Penentuan Tingkat Kompetisi Tajuk Tegakan Jati Hasil Uji Keturunan umur 11 Tahun di KPH Ngawi. Jurnal Ilmu Kehutanan, 6(2).

Smith, R. G. B., Glencross, K., Nichols, J. D., Palmer, G., \& Viranamangga, R. (2016). Effect of Initial Spacing on First Thinning Product Recovery, and Financial Outcomes in
Whitewood (Endospermum medullosum) Plantations in Vanuatu. Small-Scale Forestry, 15(1), 45-59. https://doi.org/10.1007/s11842015-9307-9

Suryani, E., \& Dariah, A. (2012). Peningkatan Produktivitas Tanah Melalui Sistem Agroforestri. Jurnal Sumberdaya Lahan, 6(2). https://doi.org/10.2018/jsdl.v6i2.6394

Warman, G. R., \& Kristiana, R. (2018). Mengkaji Sistem Tanam Tumpangsari Tanaman Semusim. Proceeding Biology Education Conference, 15(1), 791-794.

Yahya, A., Saaiffudin, K. A., \& Noor, H. M. (2011). Growth response and yield of plantationgrown teak (Tectona grandis) after low thinning treatments at Pagoh, Peninsular Malaysia. Journal of Tropical Forest Science23(4),

453-459. 
Jurnal Pemuliaan Tanaman Hutan

Vol. 15 No. 1, Juni 2021, p. 11 - 21 